TECHNICAL TRANSACTIONS 5/2018

CZASOPISMO TECHNICZNE 5/2018

CIVIL ENGINEERING

DOI: $10.4467 / 2353737$ XCT.18.074.8556 SUBMISSION OF THE FINAL VERSION: 04/05/2018

\author{
Magdalena Grudzińska (m.grudzinska@pollub.pl) \\ Department of Construction, Faculty of Civil Engineering and Architecture, Lublin \\ University of Technology
}

\title{
GREENHOUSE SYSTEMS IN QUASI-STATIONARY AND DYNAMIC
}

\section{MODELLING}

SYSTEMY SZKLARNIOWE W MODELOWANIU QUASI-STACJONARNYM

I DYNAMICZNYM

\begin{abstract}
The ISO 13790 standard presents two quasi-stationary calculation methods for including greenhouse systems in the evaluation of a building's energy balance - a detailed and a simplified method. These adopt different assumptions with regard to solar gains in sunspace and in adjacent heated rooms; thus, the calculation results of the internal temperature of the sunspace and the energy demand in heated spaces may differ. This work presents the comparison of energy effects achieved due to the sunspace in an example living space, calculated by means of both quasi-stationary methods and more accurate dynamic simulations with an hour time step. Analysis of the results obtained by means of the described methods has enabled the identification of the advisable range of each of the calculation methodologies.
\end{abstract}

Keywords: passive greenhouse systems, ISO 13790, dynamic simulations, energy demand

\section{Streszczenie}

Norma ISO 13790 prezentuje dwie metody uwzględniania systemów szklarniowych w bilansie energetycznym budynku - metodę pełną i uproszczoną. Oparte są one na różnych założeniach dotyczących modelowania zysków słonecznych w szklarni i przyleglych pomieszczeniach mieszkalnych, tak więc wyniki obliczeń temperatury wewnętrznej i zapotrzebowania na ciepło mogą się różnić. W artykule porównano efekty energetyczne uzyskane dzięki zastosowaniu szklarni przylegającej do przykładowego pomieszczenia mieszkalnego, wyznaczone za pomocą obu metod quasi-stacjonarnych i bardziej dokładnego modelowania dynamicznego z krokiem godzinowym. Analiza wyników pozwoliła na zaproponowanie zalecanego zakresu stosowania każdej z metod obliczeniowych.

Słowa kluczowe: pasywne systemy szklarniowe, ISO 13790, symulacje dynamiczne, zapotrzebowanie na energię 


\section{Introduction}

Greenhouse systems are an important element of energy-efficient architecture oriented for the passive use of solar radiation $[3,7]$. The non-heated sunspace influences the transmission of energy in a building, reducing heat loss from adjacent rooms. In order to adequately estimate the potential gains connected with the use of a greenhouse system, it is necessary to properly take it into account the energy balance of the building. One of the possibilities for carrying out such analyses is the methodology included in the ISO 13790 standard [5]. Quasi-stationary methods designed for the purpose of engineering calculations are based on the assumption of there being a steady heat flow through the constructional partitions. Calculations are carried out using climatic parameters averaged for lengthy periods of time (usually one month) and the phenomena connected with the dynamic processes such as heat accumulation and release are taken into account due to the introduction of a dimensionless gain utilisation factor.

The E enclosure of standard [5] includes two calculation methods for sunspaces - the detailed method and the simplified version - these differ in their basic assumptions as well as the manner in which they take into account the solar gains within the confines of the sunspace area and the adjacent heated spaces. The work presents the comparison of energy effects achieved as a result of a sunspace in an example living space, calculated by means of both methods relating to the quasi-stationary state and more accurate dynamic simulations with an hour time step. The results have enabled establishing the advisable range of each of the calculation methodologies.

\section{ISO 13790 methodology}

\subsection{Calculating heat gains from the sunspace - the detailed method}

The method presented in standard [5] is only relevant for sunspaces without either heating or cooling. Heat losses through partition walls between the living space and the sunspace are determined whilst taking into account the temperature correction factor $b_{t r}$, which refers to heat release to an area with a higher level of temperature than the outside temperature. The influence of solar gains upon the sunspace temperature $\theta_{s}$ is not taken into account; only heat transmission through the partition wall and the sunspace casing is considered. This is compensated for by taking account of the indirect solar gains from the sunspace $Q_{s i}$ in the energy balance of the living space. The temperature correction factor is calculated as:

$$
\begin{gathered}
b_{t r}=\frac{\theta_{\mathrm{int}, H}-\theta_{s}}{\theta_{\mathrm{int}, H}-\theta_{e}}=\frac{H_{s e}}{H_{i s}+H_{i s}} \\
\theta_{s}=\frac{\theta_{\mathrm{int}, H} \cdot H_{i s}+\theta_{e} \cdot H_{s e}}{H_{i s}+H_{s e}}
\end{gathered}
$$


where:

$\theta_{\mathrm{int}, H}-$ internal temperature in the heating period $\left[{ }^{\circ} \mathrm{C}\right]$,

$\theta_{e} \quad-$ average external temperature during the calculation period $\left[{ }^{\circ} \mathrm{C}\right]$,

$\theta_{s} \quad-$ average internal temperature in the sunspace during the calculation period $\left[{ }^{\circ} \mathrm{C}\right]$,

$H_{i s} \quad-$ heat transfer coefficient of the partition wall between the living space and the sunspace $[\mathrm{W} / \mathrm{K}]$,

$H_{\text {se }} \quad$ - heat transfer coefficient of the sunspace envelope to the outside $[\mathrm{W} / \mathrm{K}]$.

Heat gains in the heated part of the building $Q_{s}[\mathrm{MJ}]$ obtained through the sunspace are treated as the sum of direct $Q_{s d}$ and indirect $Q_{s i}$ gains:

$$
Q_{s s}=Q_{s d}+Q_{s i}
$$

Direct heat gains reach the air-conditioned area through the partition wall between the sunspace and the living space. These gains result from repeated transmission (first through the glazing of the sunspace and then through the glazed elements, e.g. windows or the door in the partition wall) or the transmission and absorption of radiation on the partition surface. According to [5], direct heat gains are calculated as:

$$
Q_{s d}=F_{s h, e} \cdot\left(1-F_{F, \mathrm{e}}\right) \cdot \mathrm{g}_{e} \cdot\left(\left(1-F_{F, w}\right) \cdot g_{w} \cdot A_{w}+\alpha_{p} \cdot A_{p} \cdot \frac{H_{p, \text { tot }}}{H_{p, e}}\right) \cdot I_{p} \cdot t
$$

where:

$F_{s h, e} \quad-$ shading correction factor taking into account shading from external obstacles [-],

$F_{F, e}$ - frame area fraction in the sunspace envelope [-],

$F_{F, w}-$ frame area fraction in the window in the partition wall [-],

$g_{e} \quad-$ effective total solar energy transmittance of glazing in the sunspace envelope [-],

$g_{w} \quad$ - effective total solar energy transmittance of glazing in the window in the partition wall [-],

$A_{w} \quad$ - area of the window in the partition wall $\left[\mathrm{m}^{2}\right]$,

$A_{p} \quad$ - area of the opaque part of the partition wall $\left[\mathrm{m}^{2}\right]$,

$\alpha_{p} \quad-$ solar absorption factor of the opaque part of the partition wall $[-]$,

$\stackrel{p}{H_{p, t o t}}$ - total heat transfer coefficient between the internal environment and the outer environment (through the partition wall and the sunspace envelope) $[\mathrm{W} / \mathrm{K}]$,

$H_{p, e}$ - total heat transfer coefficient between the absorbing surface of the partition wall and the outer environment $[\mathrm{W} / \mathrm{K}]$,

$I_{p} \quad$ - solar irradiance on the partition wall surface during the calculation period $\left[\mathrm{W} / \mathrm{m}^{2}\right]$,

$t \quad-$ duration of the calculation period $[\mathrm{Ms}]$.

Indirect gains are gains released to the air within the sunspace by means of the sunspace casing absorbing solar radiation and heating up. These are treated as gains coming from the non-heated space with the correction factor $\left(1-b_{t r}\right)$ - they are calculated by summing up the gains coming from every opaque absorbent surface within the capacity of the sunspace and subtracting the gains directly transmitted through the partition wall by the way of conduction: 


$$
Q_{s i}=\left(1-b_{t r}\right) \cdot F_{s h, e} \cdot\left(1-F_{F, e}\right) \cdot g_{e} \cdot \sum_{j}\left(I_{j} \cdot \alpha_{j} \cdot A_{j}\right)-F_{s h, e} \cdot\left(1-F_{F, e}\right) \cdot g_{e} \cdot \alpha_{p} \cdot A_{p} \cdot \frac{H_{p, t o t}}{H_{p, e}} \cdot I_{p} \cdot t .
$$

where:

$I_{j}$ - solar radiation on surface ' $j$ ' of the sunspace internal envelope in the calculation period $\left[\mathrm{W} / \mathrm{m}^{2}\right]$,

$\alpha_{j}-$ solar absorption factor of the opaque part of the sunspace internal envelope [-],

$A_{j}^{\prime}$ - area of the surface ' $j$ ' of the sunspace opaque internal envelope $\left[\mathrm{m}^{2}\right]$ (the rest of the symbols are as explained above).

\subsection{Calculating heat gains from the sunspace - the simplified method}

On a national level, it is permissible to use the simplified method including the following modifications:

- in the living space, the solar gains from the sunspace are disregarded - the heat balance does not include either direct gains transferred through the opaque and glazed parts of the partition wall or indirect gains due to absorption through the sunspace casing

- these gains are considered by employing the temperature correction factor $b_{t r}^{*}$ during the calculation of the heat transmission from the heated space to the sunspace; it is then assumed that the temperature in the sunspace $\theta_{s}^{*}$ is a result not only of the inflow and the outflow of heat through the casing (as in the detailed method) but also of the solar gains:

where:

$$
\begin{gathered}
b_{t r}^{*}=\frac{\theta_{\mathrm{int}, H}-\theta_{s}^{*}}{\theta_{\mathrm{int}, H}-\theta_{e}} \neq b_{t r}=\frac{H_{s e}}{H_{i s}+H_{s e}} \\
\theta_{s}^{*}=\frac{\Phi_{u}+\theta_{\mathrm{int}, H} \cdot H_{i s}+\theta_{e} \cdot H_{s e}}{H_{i s}+H_{s e}}
\end{gathered}
$$

$\Phi_{u}-$ average solar gains in the sunspace during the time step $[\mathrm{W}]$ (the rest of the symbols are as explained above).

\section{Dynamic simulations}

Simulation methods of greater complexity require the execution of computer calculations. The calculation step adopted here is much shorter than in the quasi-stationary methods it may be, for example, one hour or a dozen or so minutes. Depending upon temperature changes and solar irradiance, this step enables taking into account the processes of heat exchange as discrete dynamic processes [1]. Dynamic simulations may also serve as a certain kind of 'validation' of less accurate methods, such as quasi-stationary methods $[6,8,9,11]$.

Postulates concerning the possibility of using the generally available simulation tools for modelling greenhouse systems formulated on the basis of various research works $[12,15,17]$ 
are included in paper [4]. The main demands that should be met by the computer programs in order to properly calculate the solar gains in highly glazed spaces are as follows:

- the possibility to define the real geometry of the space and the glazed elements taking into account their dimensions, placement in the partitions and situation concerning geographical location; it is also necessary to take into account directional optical properties of the glazing,

- the thorough analysis of the solar radiation reaching the casing of the spaces taking into account division into the directional and the diffuse component and also the precise modelling of the radiation falling on the inclined surfaces (e.g. with the use of models taking into account anisotropy of the diffuse radiation),

- the description of radiation transmitted into the spaces taking into account the actual path of the beam passing through the glazing - it is not sufficient to differentiate the directional radiation falling at the particular internal partitions according to the absorptance-weighted area ratios or the view factors used for modelling the radiation heat exchange,

- the possibility of taking into account the long-wave radiation heat exchange with the sky.

In the current paper, the calculations are performed by means of the BSim program fulfilling the above recommendations [18]. For every air zone of the building under investigation, a balance is formulated which takes into account the heat stream passing through the casing, solar irradiance transmission through transparent elements, heat streams generated by the installation systems and transmitted through ventilation and infiltration or inter-zone air mixing. The necessary climate input parameters include air temperature, the intensity of direct and diffuse solar radiation and the relative air humidity. Data concerning wind direction and velocity may also be necessary, especially if there is a need to model the air exchange more precisely.

\section{Comparison of the presented calculation methods}

The energy demand obtained for an example living space adjacent to the sunspace and designated by means of the detailed and simplified ISO 13790 algorithms is presented below. Some adjustments (fully described in [2]) were introduced to the original equations in order to model the distribution of solar irradiance within the sunspace. The results were compared with the dynamic simulations of the same room layout which were performed with assumptions as similar as possible to the assumptions of the stationary state methods.

The living space has two outer walls - the southern wall (adjacent to a glazed balcony) and the western wall. The glazing of the balcony is at a height of $1.1 \mathrm{~m}$ (Fig. 1) and the absorption coefficient of the inner surfaces of the sunspace envelope is $0.2,0.5$ and 0.8 . The insulating properties of the living space partitions are relatively high - this is characteristic of buildings constructed in Poland after 2014 (Table 1). In addition to the solar gains in the living space, there are also internal heat gains at a level of $3.0 \mathrm{~W} / \mathrm{m}^{2}$. The air exchange in the room is $0.5 \mathrm{l} / \mathrm{h}$ and is transferred from the outside in order to fulfil the assumption of standard [5] concerning 
the lack of air flow between the sunspace and the conditioned space. The climate data used for the calculation was the data of a typical meteorological year in Warsaw [17].
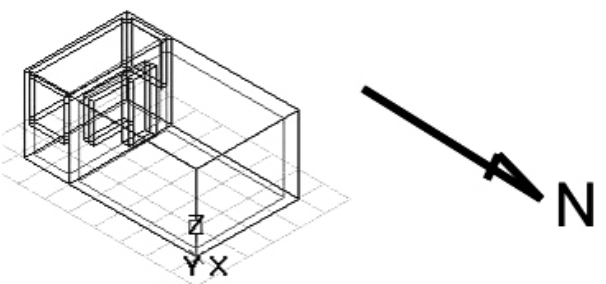

Fig. 1 . The outline of a room and a sunspace in the BSim program

Table 1. Selected parameters of building partitions

\begin{tabular}{|c|c|c|c|c|}
\hline \multirow{2}{*}{ No. } & \multirow{2}{*}{ Partition type } & \multicolumn{2}{|c|}{ Thermal transmittance coefficient $\left[\mathbf{W} / \mathbf{m}^{2} \mathbf{K}\right]$} & $\begin{array}{c}\text { Total solar energy } \\
\text { transmittance }[-]\end{array}$ \\
\cline { 3 - 5 } & & Opaque part & Window & Glazing \\
\hline 1 & living space & 0.24 & $1.20-1.23$ & 0.63 \\
\hline 2 & balcony & 0.50 & $1.66-1.69$ & 0.62 \\
\hline
\end{tabular}

In the calculations prepared according to the ISO 13790, the distribution of the solar radiation falling upon particular surfaces of the sunspace was determined as proportional to the absorptive properties of the surfaces and their areas; it is the simplest method quoted by literature $[12,13,15]$.

For the purposes of comparing the chosen calculation methods, the parameters of air temperature in the sunspace and energy demand in the living space are presented below in Tables 2 and 3.

Table 2. Air temperature $\left[{ }^{\circ} \mathrm{C}\right]$ in the sunspace during the heating season, DS - dynamic simulation, ISO d - detailed method, ISO s - simplified method

\begin{tabular}{|c|c|c|c|c|c|c|c|c|c|c|c|c|}
\hline \multirow{2}{*}{ No. } & \multirow{2}{*}{$\begin{array}{c}\text { Envelope } \\
\text { absorptivity }\end{array}$} & \multirow{2}{*}{ Method } & \multicolumn{9}{|c|}{ Month } & \multirow{2}{*}{ MAPE } \\
\hline & & & IX & $\mathbf{X}$ & XI & XII & I & II & III & IV & $\mathbf{V}$ & \\
\hline 1 & \multirow{3}{*}{$\alpha=0.2$} & DS & 19.2 & 13.6 & 8.4 & 6.3 & 5.6 & 6.2 & 11.6 & 13.7 & 19.3 & \\
\hline 2 & & ISO d & 14.2 & 10.4 & 6.2 & 4.5 & 2.8 & 3.1 & 7.4 & 8.9 & 13.7 & $34.0 \%$ \\
\hline 3 & & ISO s & 27.3 & 18.6 & 10.3 & 7.8 & 8.5 & 10.0 & 18.5 & 23.7 & 32.6 & $48.8 \%$ \\
\hline 4 & \multirow{3}{*}{$\alpha=0.5$} & DS & 21.1 & 14.8 & 9.0 & 6.7 & 6.3 & 7.0 & 13.2 & 15.4 & 21.6 & \\
\hline 5 & & ISO d & 14.2 & 10.4 & 6.2 & 4.5 & 2.8 & 3.1 & 7.4 & 8.9 & 13.7 & $40.2 \%$ \\
\hline 6 & & ISO $\mathrm{s}$ & 27.3 & 18.6 & 10.3 & 7.8 & 8.5 & 10.0 & 18.5 & 23.7 & 32.6 & $34.2 \%$ \\
\hline 7 & \multirow{3}{*}{$\alpha=0.8$} & DS & 22.0 & 15.3 & 9.2 & 6.8 & 6.6 & 7.4 & 13.8 & 16.1 & 22.6 & \\
\hline 8 & & ISO d & 14.2 & 10.4 & 6.2 & 4.5 & 2.8 & 3.1 & 7.4 & 8.9 & 13.7 & $42.0 \%$ \\
\hline 9 & & ISO s & 27.3 & 18.6 & 10.3 & 7.8 & 8.5 & 10.0 & 18.5 & 23.7 & 32.6 & $29.0 \%$ \\
\hline
\end{tabular}

According to both the detailed and simplified ISO 13790 method, the ability of the inner surfaces of the sunspace casing to absorb radiation does not influence its inner temperature. The temperature is identified as being dependent only on heat inflow and outflow through 
transmission or as a derivative of the total solar gains passing through the glazing and the thermal properties of the casing. As a result of the assumptions, the detailed method underestimates and the simplified method overestimates the interior temperatures - this can be clearly seen in the spring and autumn months (Fig. 2). Dynamic simulation results prove the increase of inner temperature along with the increase of absorption properties of the surface. Temperature assumes the intermediate values between the results obtained for the detailed and simplified method that may be regarded as the upper and lower limits of the actual inside temperature.

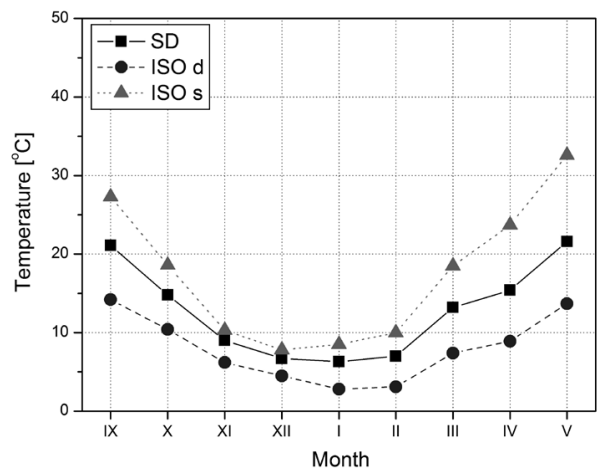

Fig. 2. Air temperature in the sunspace during the heating season, $\alpha=0.5$

The average monthly temperatures obtained from the particular methods were compared with the dynamic simulation results with the use of the mean absolute percentage error (MAPE):

$$
\mathrm{MAPE}=\frac{100}{n} \sum_{i=1}^{n}\left|\frac{A_{i}-F_{i}}{A_{i}}\right|
$$

where:

$n$ - number of predicted values,

A - exact value (based on the dynamic simulations),

$F$ - predicted value (based on the ISO 13790 calculation method).

If the MAPE value $>15 \%$ (which is true for all cases), then the forecasts are inaccurate and should not be accepted for the analysis of the phenomena [14]. Neither of the ISO 13790 methods can be considered to be accurate enough for predicting the sunspace air temperature.

Neither of the ISO 13790 methods are supposed to accurately represent the course of heat demand in the particular months of the heating season, but only to produce a close counterpart for the more accurate final result. On the basis of the MAPE values, the monthly course of heat demand cannot be counted among the acceptable forecasts (MAPE $\leq 15 \%$ acc. to [14]).

The quasi-stationary ISO 13790 methods should be 'conservative' methods by assumption, i.e. they should overestimate the seasonal heat demand in comparison to the calculations using the hour time step, whereas the detailed method (as the more accurate version) should present a lower heat demand. Such a regularity can be seen in two calculation cases $-\alpha=0.5$ and 0.8 . In these cases, the differences between the detailed ISO 13790 method and the simulations are 
from $7.1 \%$ to $15.5 \%$ and the differences between the simplified ISO method and the simulations are from almost $21 \%$ to $28 \%$. Approximation of this kind, in the author's opinion, may be regarded as satisfying in the engineering calculations.

Table 3. Energy demand in the living space [kWh] during the heating season, DS - dynamic simulation,

ISO d - detailed method, ISO s - simplified method

\begin{tabular}{|c|c|c|c|c|c|c|c|c|c|c|c|c|c|c|}
\hline \multirow[b]{2}{*}{ No. } & \multirow{2}{*}{$\begin{array}{c}\text { Envelope } \\
\text { absorpti- } \\
\text { vity }\end{array}$} & \multirow[b]{2}{*}{ Method } & \multicolumn{9}{|c|}{ Month } & \multirow[b]{2}{*}{ Sum } & \multirow{2}{*}{$\begin{array}{c}\text { ISO/ } \\
\text { SD }^{*}\end{array}$} & \multirow[b]{2}{*}{ MAPE } \\
\hline & & & IX & $\mathbf{X}$ & XI & XII & I & II & III & IV & $\mathbf{V}$ & & & \\
\hline 1 & \multirow{3}{*}{$\alpha=0.2$} & DS & 0.4 & 59.5 & 130.8 & 164.6 & \begin{tabular}{|l}
171.4 \\
\end{tabular} & \begin{tabular}{|l|l}
150.4 \\
\end{tabular} & 92.3 & 63.9 & 17.1 & \begin{tabular}{|l|}
850.4 \\
\end{tabular} & & \\
\hline 2 & & ISO d & 8.2 & 78.0 & 153.7 & \begin{tabular}{|l}
187.8 \\
\end{tabular} & 203.4 & 176.0 & 113.0 & 73.1 & 3.7 & 996.8 & $17.2 \%$ & $34.8 \%$ \\
\hline 3 & & ISO $\mathrm{s}$ & 0.0 & 66.8 & 148.2 & 183.2 & 195.6 & \begin{tabular}{|l}
167.4 \\
\end{tabular} & 97.6 & 53.2 & 0.0 & 912.0 & $7.2 \%$ & $31.6 \%$ \\
\hline 4 & \multirow{3}{*}{$\alpha=0.5$} & DS & 0.0 & 42.1 & 124.2 & \begin{tabular}{|l|}
159.8 \\
\end{tabular} & 163.3 & \begin{tabular}{|l|l}
141.5 \\
\end{tabular} & 74.2 & 43.6 & 6.1 & 754.7 & & \\
\hline 5 & & ISO d & 1.2 & 60.2 & 145.0 & 180.5 & 190.9 & 162.4 & 88.5 & 42.8 & 0.3 & 871.8 & $15.5 \%$ & $24.6 \%$ \\
\hline 6 & & ISO s & 0.0 & 66.8 & 148.2 & 183.2 & 195.6 & \begin{tabular}{|l}
167.4 \\
\end{tabular} & 97.6 & 53.2 & 0.0 & 912.0 & $20.8 \%$ & $31.6 \%$ \\
\hline 7 & \multirow{3}{*}{$\alpha=0.8$} & DS & 0.0 & 35.0 & 121.1 & \begin{tabular}{|l|}
157.5 \\
\end{tabular} & 159.4 & \begin{tabular}{|l|}
137.3 \\
\end{tabular} & 65.7 & 36.0 & 1.1 & 713.0 & & \\
\hline 8 & & ISO d & 0.2 & 43.0 & 136.2 & \begin{tabular}{|l|}
173.2 \\
\end{tabular} & 178.5 & \begin{tabular}{|l|l|}
148.7 \\
\end{tabular} & 64.5 & 19.1 & 0.0 & \begin{tabular}{|l}
763.4 \\
\end{tabular} & $7.1 \%$ & $23.6 \%$ \\
\hline 9 & & ISO s & 0.0 & 66.8 & 148.2 & 183.2 & 195.6 & \begin{tabular}{|l|}
167.4 \\
\end{tabular} & 97.6 & 53.2 & 0.0 & 912.0 & $27.9 \%$ & $41.2 \%$ \\
\hline
\end{tabular}

* change of the total energy demand during the heating season in the ISO method compared with dynamic simulations

The results obtained for the smaller absorptive surface properties $(\alpha=0.2)$ may evoke certain doubts with regard to the accurate representation of the physical processes of both

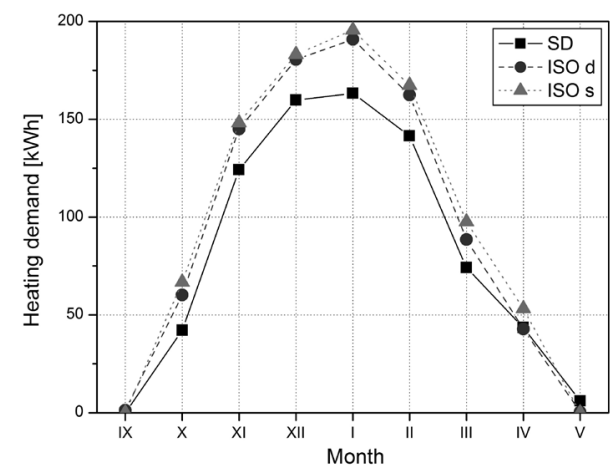

Fig. 3. Energy demand in the room during the heating season, $\alpha=0.5$

methods of standard [5]; however, the differences between them and the dynamic simulations at worst approach $17.2 \%$. If the absorptive properties of the surface of the sunspace casing are small, the detailed ISO method presents the highest energy demand which results from connecting the smaller direct solar gains with an insufficient regard for the buffer effect of the sunspace resulting from the underrated internal temperature and the indirect gains. In the case of lower absorptive properties, the simplified ISO method has proved to be closer to the dynamic simulations as it overestimates the buffer effect of the sunspace. 


\section{Summary}

To confirm, the ISO 13790 methods enable the satisfactory representation of an example sunspace with a relatively small proportion of glazed partitions and a higher radiation absorption inside the casing, i.e. a space similar to traditional spaces as far as the utilisation of solar radiation is concerned. The phenomena typical of highly glazed spaces (specifically, the retransmission of reflected radiation) are not satisfactorily taken into account in the calculation methodology of the ISO standard. This causes greater divergence between the results obtained for the high reflectivity of the casing surface.

It is necessary to remember that the above analyses were carried out for a particular radiation distribution inside the sunspace. Adopting a more precise representation of radiation on the surface [16] could influence the accuracy of the calculations; however, a detailed analysis of the radiation route exceeds the scope of engineering calculations for which the ISO 13790 methodologies were designed.

Out of all the presented calculation methods, dynamic simulation is the technique which takes the largest number of factors into account which influence the functioning of a sunspace, these are:

- the spatial character of solar radiation,

- the optical properties of glazing with regard to the function of the radiation angle of incidence,

- radiation retransmission resulting from reflections within the sunspace,

- various absorptive properties of surfaces,

- sunspace ventilation and the air flow between the sunspace and the conditioned accommodation.

Thus, dynamic simulation is the method of greatest research potential, provided that it is appropriately used and that the results obtained are validated as much as possible in the conditions of the actual functioning of the objects in question.

\section{Acknowledgments}

This work was financially supported by Ministry of Science and Higher Education in Poland, within the statutory research number $S / 14 / 2018$.

\section{References}

[1] Clarke J.A., Energy Simulation in Building Design, Butterworth-Heinemann, Oxford 2001.

[2] Grudzińska M., Zyski energetyczne w systemach szklarniowych - porównanie metod obliczeń wg ISO 13790, XVI Polska Konferencja Naukowo-Techniczna: Fizyka Budowli w Teorii i Praktyce, 20-22 czerwca 2017, 39-48.

[3] Hestnes A.G., Hastings S.R., Saxhof B., Solar Energy Houses: Strategies, Technologies, Examples, James \& James Science Publishers Ltd, London 1996. 
[4] Hilliaho K., Lahdensivu J., Vinha J., Glazed space thermal simulation with IDA-ICE 4.61 software - suitability analysis with case study, Energy and Buildings, 89, 2015, 132-141.

[5] ISO 13790:2008 Energy performance of buildings. Calculation of energy use for space heating and cooling, Switzerland: International Organization for Standardization.

[6] Jokisalo J., Kurnitski J., Performance of EN ISO 13790 utilisation factor heat demand calculation method in a cold climate, Energy and Buildings, 39, 2007, 236-247.

[7] Passive and hybrid solar low energy buildings. Passive solar homes: case studies, eds. Kok H., Holtz M.J., International Energy Agency, Solar Heating and Cooling Program, Task VIII, Design information booklet no. 6, December 1990.

[7] Kokogiannakis G., Strachan P., Clarke J., Comparison of the simplified methods of the ISO 13790 Standard and detailed modelling programs in a regulatory context, Journal of Building Performance Simulation, 1, 2008, 209-219.

[8] Leenknegt S., Saelens D., Comparison between simplified and dynamic calculation of highly glazed spaces, Proceedings of the 1st Central European Symposium on Building Physics, Cracow-Lodz, September 2010, 335-342.

[9] Narowski P., Daneklimatyczne do obliczeń energetycznych wbudownictwie, Ciepłownictwo, Ogrzewnictwo, Wentylacja, 11, 2006, 22-27.

[10] Oliveira Panão M.J.N., Camelo S.M.L., Gonçalves H.J.P., Solar Load Ratio and ISO 13790 methodologies: Indirect gains from sunspaces, Energy and Buildings, 51, 2012, 212-222.

[11] Oliveti G., De Simone M., Ruffolo S., Evaluation of the absorption coefficient for solar radiation in sunspaces and windowed rooms, Solar Energy, 82, 2008, 212-219.

[12] Passerini F., Albatici R., Frattari A., Quasi-steady state calculation method for energy contribution of sunspaces: a proposal for the European standard improvement, Proceedings of Building Simulation Applications BSA 2013, $1^{\text {st }}$ IBPSA Italy Conference, BozenBolzano, Italy, 141-150.

[13] Rogalska M., Wieloczynnikowe modele w prognozowaniu czasu procesów budowlanych, Lublin University of Technology, Lublin 2016.

[14] Roux J.J., Teodosiu C., Covalet D., Chareille R., Validation of a glazed space simulation model using full-scale experimental data, Energy and Buildings, 36, 2004, $557-565$.

[15] Tiwari G.N., Gupta A., Gupta R., Evaluation of solar fraction on north partition wall for various shapes of solarium by Auto-Cad, Energy and Buildings, 35, 2003, 507-514.

[16] Wall M., Climate and energy use in glazed spaces, Report TABK-96/1009, Lund University, Department of Building Science, Lund 1996.

[17] Wittchen K.B., Johnsen K., Grau K., BSim user's guide, Danish Building Research Institute, Hørsholm 2004. 